\title{
Sailing upwind or a fresh and salt watered history of design
}

\author{
A. Can Özcan / Izmir University of Economics / Izmir / Turkey
}

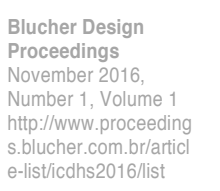

\begin{abstract}
It is interesting to see how history has neglected the waters which in reality cover more than $70 \%$ of the earth. The civilizations which have not established land settlements have been considered as extinct (like Polynesians and Phoenicians) if not named as some obscure phrases like "sea people", and the languages developed in the seas have been considered as a combination of land languages combined with a necessity to define technical aspects of boat building and/or seafairing. Starting with the multi-centered origins and multiple evolution of vessels and their components designed for fresh water and sea travel, and limiting itself with the historical design aspects of sail, this paper is a moderate attempt to argue whether a nautical design history can change our cognition of history in general.
\end{abstract}

\section{Keywords}

Historical rhetoric, design history, maritime design, boat building, lateen sail design

\section{Introduction}

"There is no document of civilization which is not at the same time a document of barbarism. And just as such a document is not free of barbarism, barbarism taints also the manner in which it was transmitted from one owner to another. A historical materialist therefore dissociates himself from it as far as possible. He regards it as his task to brush history against the grain" writes Walter Benjamin (1940) in his classical essay Thesis on the Philosophy of History essay. Though the claims in this article seem over ambitious, it is rather a moderate effort to provide not an anti-historical view, but an extended model to review the early past with a considerable amount of data regarding seas and oceans, excluding the majority of the established historical paradigms regarding Mediterranean and European originated discourse related to design history. It can also be viewed as an attempt to provide some early foundational links between world history, maritime history and design history where these three domains have lost connections mainly because, i) all three areas have developed to be well defined and clear specialization areas, and ii) marine issues and affairs have always been a unique area from the beginning with its special language, tools, and affairs. The most ambitious argument behind this article can be defined as an attempt to start a discourse on "Maritime Design History" if it does or can exist. Besides and beyond the definitions of history as an account of chronological record of events which have taken place in an unchanging past from ancient Aristoteles to "a kind of research or enquiry" into "actions that have been done in the past", conducted "by the interpretation of evidence"-evidence being further defined as documents by more contemporary R.G. Collingwood (1946), history is also a convention about the past reflecting the values which belong to the collective consciousness of the present and eliminating the ones which do not belong to it.

This article mainly deals with early maritime issues until lateen sail was invented with a specific focus on Southeast Asia and Indian Ocean for this area seems to have provided some of the the influential basics of maritime design to be credited to Mediterranean and Eurasia in the periods to come.

Dealing with maritime design history arises the question whether there exists a structurally and even chronically different history of civilization than the history we have accumulated regarding events on land which is a kind of terrestrial history. Though they are inevitably interrelated the general structure of the history we know mainly focuses on the series or repetitive events on types of land from continents to islands. From the rise and fall of civilizations to the structural categories created in the course of history, land plays the major role. From the discovery 
of the earliest humanoid bones found in Africa to early settlements and agricultural developments in Mesopotamia, and from the domestication of horse to fall (or conquer for some others) of Constantinople or the discovery (or conquest for some others) of Americas, history has been established and structured by the events bound to land.

\section{Histories of land and sea}

"But the influence of the sea on man's daily life and on his future well-being is so great and still so poorly comprehended that the sea must be explored, studied, and understood so that it can be taken into account more intelligently whenever man is faced with any problem relating to his physical environment" says H.B. Stewart in his In Deep Challenge (1966). The oceans and the seas are more important to life on earth than the rainforests by not only dictating the global weather but also by providing the world's water supply. On the other hand reckless destruction of the resources combined with severe acidification and pollution, the destruction of sea habitat is immerse and to some researchers even irreversible. The rate of the extinction or decrease of sea species are at an unsustainable rate and some of the living organisms from fishes to weeds are going extinct before they are being discovered.

According to Unesco (2016) there are close to 500 dead zones covering more than

$245,000 \mathrm{~km} 2$ globally, equivalent to the surface of the United Kingdom. Paradoxically we have more knowledge and data about UK more than entire oceans and seas. One of the causes of this destruction lies in humans' questionable attitude towards sea not excluding in terms of a historical subject. Probably people watch more space ships than actual ships on movie or television screens. Yet, like human body, almost $3 / 4$ of the surface of the earth is covered with either fresh or salt water. To be more accurate water makes up about $71 \%$ of the Earth's surface, and $96.5 \%$ of all the Earth's water is contained within the oceans as salt water, while the remaining $3.5 \%$ is freshwater lakes and frozen water locked up in glaciers and the polar ice caps (Williams, 2014). And very much like Hollywood dealing more with fictional space ships than the oceans and sea related plots, history has done a very similar attitude towards land, underestimating sea or treating it as if seas and and oceans have not been an integral paart of the chronological sets of events on land. It is not, or maybe it is, surprising to see maritime history, oceanography, or maritime archeology follow a different pattern different than the world history rhetoric.

The emphasis on the silk road, or kings' road, or the Alexander's or Crusaders' road, or the railroads after the locomotives were developed by industrial revolution have been comparatively less when compared with the trade networks of the Indian Ocean and Arabian Sea. Evidences show that people were to trade between Mesopotamia and Indus river four thousand years ago, world history doesn't seem to recognize much and still cling unto the generic rhetoric of history following the paths of land culture mainly based on transition from hunter gatherers to agricultural settlements. Migration of first settlers from Southeast Asia to Australia on rafts almost in 50.000 B.C. or the Polynesians' epic ocean voyages in the Pacific Ocean from 1000 BC to 1500 AD with their possible trips to the east coasts of America remain as underrated marginal stories historical rhetoric. While the world history traditionally focus on political, religious, or cultural issues, issues like maritime trade, explorations, sea migrations, or naval subjects remain as a distinctive domain within maritime history (Paine, 2014). Design history, on another domain, while following the rhetoric of world history through a chronological order prefers not to touch upon maritime issues in a similar way. Like maritime language remains alien to land language, maritime history remains alien to world history and design history. In addition to this alienated historical approach Eurocentric attitude towards not only world history but Maritime issues create another set of complexities. Not only the generic world map, but also the world history and historical maritime developments have always been viewed as a European followed by American phenomenon.

The emphasis on Columbus' first voyage to the Americas in 1492, followed by Vasco Da Gama's to India and Magellan's circumnavigation of the earth in late 15th and 16th centuries, or James Cook's half colonial half scientific expedition in the Pacific Ocean have always been more than the maritime achievements of the Arabs', Polynesians', Southeast Asians', Vikings' or Chinese and Japanese maritime achievements of the times before them, not to mention a continent totally ignored, Africa. Maritime design history provides evidence that people especially alongside the East coast of Africa and alongside the North African shores by the Mediterranean from Tunis to Alexandria and Antioch have played major roles developing a civilization based on maritime affairs from trade to fishing, from boat building to sail design. On the contrary seas and oceans other than Mediterranean seems to have played the major roles until the Mediterranean and the continents around Mediterranean have defined world history from first settlements in and around Mesopotamia to the invention of Sumerian writing, from the Bronze Age in Asia Minor to Mediterranean empires from Egyptians to Romans, Byzantines and Ottomans. 


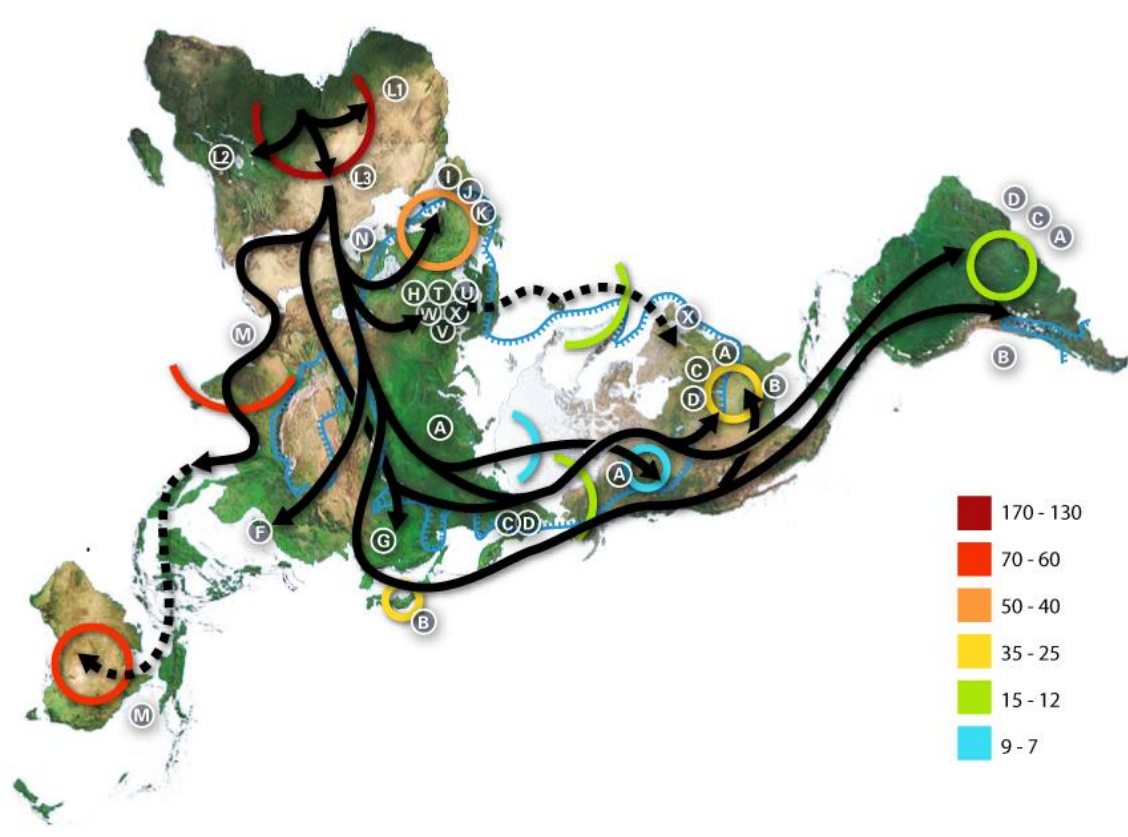

Fig.1 Human Migration on Fuller's Dymaxion Map Projection. The numbers refer to thousand years before present (Source: Wikimedia Commons

https://commons.wikimedia.org/wiki/File:Map-of-human-migrations.jpg, last accessed Feb.01, 2016)

human kind should have survived through two ice ages and the intervals between them in the last almost three millions of years (Fuller, 1982, p.11). An ice age lowers the ocean level and reveals connections between land masses. These ice ages must have made some migrations of humans and animals possible and easier from one continent to another as in the case of Asia to America through Bering from Siberia to Alaska, or from Southeast Asia to the islands all the way to Australia. First expanding and then melting of ice masses, filling the solid oceans with water and latter developments through millions of years should have separated these people from once they've originated from and let them develop their own cultures socially and even biologically independently, forming the ethnical and anthropological origins of today. Through these prehistoric courses of developments people should have developed first boats making transportation possible on fresh waters running from the heights of high Himalayas.

The diversity and population of not only people of Far East and South East Asia but also of cultures, beliefs, religions, languages can overcome every continent even today. More than half of the world population is still living in India, China and Southeast Asia today where a little more than $30 \%$ is in Europe and almost $15 \%$ is in Americas, The separation of continents and islands by seas could have been the reason two different sets of cultures emerged in latter periods, one settled in big continents of Eurasia, Africa and Americas while the others formed islanded sea people of Southeast Asia Islands, Polynesians, or people of Marshall Islands who developed totally a different design paradigm of Pacific Ocean map from bamboo sticks for example. The melting of the ice from top of the mountains and hills of Southeast Asia and the need for fresh water on islands and sea shore lands of the continents should also have started the design and production of first sea, river and canal transportation boats in the same continent which could have become the riverine trade vessels for thousands of years followed by much capable designs equipped with oars and sails to go further towards west from Philippine Sea to Red Sea and East Africa along the Indian Ocean.

Chang Ziang, Xi Ziang, Mekong, Salween, Irrawaddy, Brahmaputra, Ganges and Indus rivers from East to West form a similar pattern of fresh water ways from Himalaya tops towards different ashore centers thus also forming design cradles for the foundations of maritime design both for fresh water currents, and, wind and sea navigation. And Columbus' interest to reach India could also be shared by Alexander the Great for the very same reason that "Ex Oriente Lux"* not because there were Silk Road and King's Highway, but also a very well established sea routes running between Mediterranean and Indian Ocean. The wealth running up and down the river Nile was the reason to build the city of Alexandria which then turned out to be one of the boatbuilding and trade centers of the Mediterranean for distribution. The voyages up and down the river Nile, Red Sea and Persian Gulf accompanied with the trade roads along North-South axis could have made a design interaction as well in terms of boat building which 
made both ends benefiting from the designs of the other end. This hypothesis require one essential maritime design to be developed, a ship which is capable of going not with but also toward the wind, equipped with a set of strong hull and power to go upwind, which is impossible with oar or rudder like designs being used in rivers.

\section{Dhows and lateen sails}

The earliest depiction of square sailed boats can be found on Egyptian pottery going back to 3100 BC (Lavery, 2004, p.21). The Nile with winds blowing from north to south and the currents flowing from south to North have made Egyptian boats sail upstream, hoisting a large rectangular sail, and then are rowed back down the river. The wealth of Egyptians followed by Babylonians, Phoenicians and Nabateans/Arabs depend on their North-South water and land ways from the river Nile towards east including Red Sea, Arabian Peninsula and Persian Sea, not to mention Mediterranean. It is no surprise that the first fictional account of a ship in history, Noah's Ark, also belongs to the narratives of this region from The Book of Genesis in the Bible to Islamic Quran. The natural and social diversity of the Indian Ocean ecology from the East Coasts of Africa to Southeast Asia has also has also brought diverse cultures and technologies into close contact and interdependence including maritime design as in the case of dhows. Tropical forests in east Africa and India could have provided the raw material of shipbuilding, and shipyards and India's cotton for sails, iron nails, and coir ropes were essential materials. The Arabian Peninsula and the Gulf, lacking these resources could have supplied men, traders and laborers, who spent much of their time abroad and at sea. Eventually shipbuilding also could have taken off on the African and Arabian coasts.

Seems like while the November-February monsoon winds have made sailing westward possible, the April-September monsoons have made it eastward back and dangerous as well, between India and Egypt until Roman times and latter. The earliest capable designs which were to sail open seas seems to have derived from West Indian Arab accredited dhows combined with lateen sails. James Taylor suspects that the word dhow is of Indian/Portuguese from the times of Portuguese hegemony sounding like another Indian word padao being used for Indian sailing ships (Taylor, 2002). Though no evidence has been left regarding dhow type of sailing boats were inventions of whether Arabic West or Fareast Indian Ocean, they dominated the early sea trade routes between Red Sea and South East Asia from 600 BC onwards and their most distinctive features were their stitched planks and triangular sails. They were mainly trade and fishing vessels of different scale from huge baghlah, ganjah, or sambuk types of big offshore long distance voyagers to small barija and smallest zaruq types used for pearl fishing. Because all these words have either Arabic or Persian origins, these vessels seemed to have designed and developed in the Arabian Sea from Red Sea to Persian Gulf.

If dhows were the first ancestors of long distance voyages in terms of hull type, lateen sail was one of the most significant inventions making the ships sail upwind. Lateen sail is the triangular type of sail which allows boats sail at an angle towards the wind because of the pressure differential between sides offering less drag and versatile maneuverability compared to square type of sails which was the type of sailing downwind with the push of the wind from aft. Another type of a tilted square and upside down type of triangular V-shaped sail has been designed, developed and used by Polynesians in Western Pacific since around 2000 BC. Romans to Vikings all sailor sea civilizations from Mediterranean and Black Sea to West Atlantic and Northern Europe, used square sails if not accompanied with oars. The transition from square sails to lateen or the invention of lateen can well be explained by tilting the square sail until its axis becomes perpendicular to the wind (Campbell, 1995 p.2).

I.C. Campbell (1995), who has published one of the most valuable contributions to the development of lateen sail concludes that lateen sails were not as revolutionary as they were thought, and ii) they were neither Arab, nor Southeast Asian inventions, but were developed in Mediterranean, Southeast Asia, and West Indian Ocean independently well before Arabs and Muslims dominated the region. Accepting both arguments do not diminish i) the value of lateen sail in maritime design history, ii) the inter-trade between Mediterranean and Southeast Asia could have made invention of lateen sail not independently, but through interaction. Contrary to the boats and ships designed and used for fishing, trade, or ceremonial reasons as in the case of Egyptians until Phoenicians, Greeks' and Romans' warship designs like galleys and triremes which maybe not put an end to the thousands of years old trading cultures of the region from Mediterranean to Southeast Asia, but definitely transformed the region from a trade based geography into a land based military fight and conquer based one. Warships of the latter periods like galleys and triremes with their variants depend on oarsmen made up of the slaves of military Roman, Byzantine and Ottoman empires.

Narrow, long ships, powered by banks of oarsmen, circling each other attempting to ram the enemy and grapple the ship so that attackers can board have remained as the basic naval warfare tactic until the 
battle of Lepanto in 1571. This war between the Ottoman Empire and the coalition of Catholic maritime states has ended the domination of rowing type ships and ships equipped with sail started to gain dominance afterwards. The Europeans' Exploration Age followed by the establishment of new trade routes and seas of naval warfare between continents not only brought back sailing ships but brought them back with glamourous designs of carracks, galleons, and galleys.

Very much alike in their life on land, humans have designed diverse set of sea and water related forms, yet concepts fixed for particular purposes from better floating hulls to wind operated sails. Over time, these forms should have become refined or been transformed into new possibilities through new technological, social and cultural developments and interactions. Many concepts of sea related designs from the overall shape of boats to the specific elements of rigging probably derived from accumulated experience in practical work, before being codified and, in turn, fed back into other applications. Regarding not only the maritime or design issues, but also other historical issues as well there can be more to be found or more to be investigated regarding the role of Southeast Asia and East African Coast all the way North to Mediterranean either on land or on water remaining not only undercovered but also disappearing because of the contemporary distructive situation in the region.

\section{References}

Benjamin, Walter (1940), Thesis on the Philosophy of History, Illuminations (ed. Hannah Arendt, translated by Harry Zohn), Schocken Books, pp. 256-257

Campbell, I. C. (1995), The Lateen Sail in World History, Journal of World History, Vol.6, No. 1, University of Hawai'l Press

Collingwood, R.G. (1946) The Idea of History. Oxford University Press, pp. 9-10

Fuller, R. Buckminster (1982), Critical Path, New York: St. Martin's Press, p.22

Lavery, Brian (2004), Ship: 5000 Years of Maritime Adventure, DK Dorling Kindersley

Paine, Lincoln (2014), The Sea and Civilization, Atlantic Books, pp. 39-40

Sailors and Daughters: Early Photography and the Indian Ocean Exhibition Website: http://indian-

ocean.africa.si.edu/monsoon-dhows, last accessed Feb. 01, 2016

Stewart, H.B. (1966) In Deep Challenge (1966) N.J.: Van Nostrand, p. 17

Taylor, James (2002). Speech given to the British-Yemeni Society, The BY Society Website: http://www.albab.com/bys/articles/taylor03.htm, last accessed Feb.01. 2016

Unesco (2016): Facts and Figures on Marine Pollution: http://www.unesco.org/new/en/natural-sciences/iococeans/priority-areas/rio-20-ocean/blueprint-for-the-future-we-want/marine-pollution/facts-and-figures-onmarine-pollution/, last accessed Feb. 01, 2016

Williams, Matt (2014) What Percent of Earth is Water, Universe Today, Space and Astronomy News Dec. 1, 2014, http://www.universetoday.com/65588/what-percent-of-earth-is-water/, last accessed Jan.27, 2016)

\section{Biographical note}

Dr. Ozcan received his B.I.D (Bachelor of Industrial Design) degree from Middle East Technical University, Ankara, Turkey, and his MSc and Ph.D. degrees from Dokuz Eylul University, Institute of Social Sciences, with his studies on design semiotics. In February 2004, he was assigned to coordinate the establishment studies of the Dept. of Industrial Design at Izmir University of Economics where he was assigned as head of the department in 2006. He is also the general director of EKOTAM, Izmir University of Economics Design Research and Application Center since 2011. 